\title{
14. Regulating internships in active labour market programmes: A comparative perspective $^{1}$
}

\author{
Irene Nikoloudakis
}

\subsection{INTRODUCTION}

Internships undertaken as part of active labour market programmes (ALMPs) are an important aspect of vocational training in welfare states. They target unemployed youth with little or no professional skills and recent graduates to facilitate their transition into the labour market. ${ }^{2}$ ALMP internships often involve a tripartite relationship among the intern, a host organization and an employment services provider, most often the public employment service or other organizations delivering workfare programmes which require beneficiaries to engage in some type of activity in order to receive their benefits. Typically, the provider is responsible for recruiting job seekers and graduates for the programme, and acts as the intermediary between the intern and host organization. It assumes a supervisory role, overseeing the quality of the internship and the results of the programme. ${ }^{3}$ In contrast, the role of the host organization or the employer has been considered to a lesser extent. If a contract exists between the intern and the host organization, then the latter's responsibilities, such as providing minimum working conditions and ensuring skill development, may be included in that agreement. In some countries, the obligations of the host organization are specified in soft law, such as minis-

\footnotetext{
1 This chapter contains material originally published in Andrew Stewart, Rosemary Owens, Anne Hewitt and Irene Nikoloudakis, 'The Regulation of Internships: A Comparative Study' (2018) ILO Employment Policy Department Working Paper No 240.

2 European Commission, 'Applying the Quality Framework for Traineeships' (2016) European Commission Staff Working Document 324, 5; Directorate-General for Internal Policies, Skills Development and Employment: Apprenticeships, Internships and Volunteering (European Union 2017) 20.

3 Directorate-General for Internal Policies (n 2) 20.
} 
terial determinations and policy directives, but rarely are they mandated by legislation.

As this chapter explains, how ALMP internships are regulated for the purpose of general labour standards varies remarkably between jurisdictions. In some countries, ALMP interns have been expressly excluded from the scope of their labour laws; in others they appear to fall within their ambit; and for some it remains open to question. Perhaps what is more consistent among countries (although there are exceptions) is that occupational health and safety, discrimination and workers compensation laws apply to ALMP interns. Notwithstanding this protection, anecdotal evidence exists of ALMP interns engaging in unsafe practices that have placed their health at serious risk.

The regulation of the quality aspect of ALMP internships has also received increasing attention. While their central purpose is to facilitate the transition of interns into the labour market, in practice many ALMP internships lack the required training dimension as they are geared more towards benefiting the community than enhancing interns' skill levels. In other instances, ALMP interns engage only in the most menial of tasks which do not provide them with the capabilities and skills necessary to facilitate their entry into the modern workforce.

This chapter provides a unique analysis of a range of approaches to the regulation of ALMP internships in seven countries which have differing levels of economic development: Argentina, Australia, Canada, China, Germany, South Africa and the United States. In particular, the chapter explores the extent to which these countries regulate ALMP internships for the purposes of their labour, anti-discrimination, occupational health and safety, and workers compensation standards, before turning to examine how the quality aspect of ALMP internships is regulated. The chapter concludes by considering some future directions for the regulation of ALMP internships from a global perspective.

\subsection{LABOUR STANDARDS}

There is a myriad of ways in which internships can be and are regulated in practice for the purpose of labour standards. For example, regulation can exist at the local or institutional level and host organizations and intermediaries can develop their own rules and processes to govern the internships. However, the focus of this chapter is on the instrumental state regulation of ALMP intern- 
ships for the purpose of labour standards. According to Owens and Stewart at least five approaches may be discerned: ${ }^{4}$

- specific regulation of the use or content of internships;

- regulation by inclusion: regulation that explicitly brings internships within the scope of labour laws by either expressly defining the internships as 'employment' or extending employment rights to certain internships;

- regulation by exclusion, that is, regulation that expressly excludes internships from the scope of labour laws;

- strategic enforcement of labour laws by the state; and

- the use of soft law by the state to influence the use and content of internships and the treatment of interns.

Each of these approaches has been adopted in at least one of the countries studied. Indeed, it is not uncommon for a country to adopt more than one for different purposes.

\subsubsection{Specific Regulation and Regulation by Inclusion}

Argentina has introduced specific legislation to regulate one of its main ALMP internships, the Programa de inserción Laboral. The programme is in part regulated by Resolution MTEySS No 45/06 and Resolution SE No 2186/2010 and is implemented by the Ministry of Labor, Employment and Social Security (MTEySS). The programme is aimed at promoting the insertion of particular groups of unemployed workers into quality jobs by providing economic incentives to employers seeking to increase staff levels. Interns are required to enter into a contract of employment with the host organization, but article 12(1) of Resolution MTEySS No 45/06 cautions that no labour contract exists between the intern and the MTEySS. Employers must comply with the applicable labour and social security laws ${ }^{5}$ but, as interns receive monthly financial assistance from MTEySS, host organizations are permitted only to pay the difference necessary to reach the salary specified in the applicable collective labour agreement.

\subsubsection{Regulation by Exclusion}

In other countries, ALMP interns have been specifically excluded from some or all of the scope of their labour standards. An example of this approach 
can be found in Germany. By way of background, Germany implements two social assistance schemes: one regulated under the Second Book of the Social Code (SGB II) and the other regulated by the Twelfth Book of the Social Code (SGB XII). The SGB II applies to individuals who are unemployed, but capable of working at least three hours per day. ${ }^{6}$ As a condition of receiving financial assistance, the beneficiaries may be obliged to participate in 'temporary extra jobs' (Arbeitsgelegenheiten in der Mehraufwandsvariante), which typically involve community service and work in public infrastructure. ${ }^{7}$ Under section $16 \mathrm{~d}(7)$ of the SGB II, temporary extra jobs do not constitute an employment relationship, nor are the individuals taking part in these jobs considered unemployed. ${ }^{8}$ In addition to their welfare benefits, they receive an hourly payment of 1-2 euros from the host organization, and for this reason temporary extra jobs have been dubbed ' 1 euro jobs'. Further, section 15 of the SGB II provides that the job centre must enter into a 'reintegration agreement' (Eingliederungsvereinbarung) with the beneficiary. According to the Federal Social Court, this agreement must include the work the individual will perform, where the job will take place, the amount of compensation to be paid and the number of working hours per week. ${ }^{9}$ While the SGB II does not specify the number of hours the beneficiary must work, the jobs are typically part-time for a maximum of 30 hours per week..$^{10}$

\subsubsection{Strategic Enforcement of Labour Laws}

For some countries, whether ALMP interns fall within the ambit of their labour laws is less clear, as interns are neither explicitly included in, nor excluded from, their scope. The answer is in part dependent upon a country's level of labour law enforcement. In Australia, for instance, whether ALMP interns fall within the ambit of the Fair Work Act 2009 (Cth), the main federal labour statute, remains open to question. This is particularly the case in relation to the Prepare-Trial-Hire $(\mathrm{PaTH})$ programme, which provides young job seekers the opportunity to take part in internships. These PaTH internships are not paid by the business, although interns receive a fortnightly allowance in addition to their welfare benefits. Arguably, this fortnightly payment could constitute

\footnotetext{
6 Anja Eleveld, 'The Duty to Work Without a Wage: A Legal Comparison between Social Assistance Legislation in Germany, the Netherlands and the United Kingdom' (2014) 16 Eur J Soc Sec 204, 210.

7 Thomas Walter, Germany's 2005 Welfare Reform: Evaluating Key Characteristics with a Focus on Immigrants (Springer 2013) 79.

8 Ibid 80.

9 BSG 16 December 2008 B 4 AS 60/07 R; Eleveld (n 6) 209-10.

10 Eleveld (n 6) 210-11.
} 
'remuneration' for the purposes of the Fair Work Act 2009 (Cth) so as to preclude the operation of the 'vocational placement' exception in section 12 of the Act, which is defined to mean an unpaid placement undertaken as a requirement of an education or training course and authorized under a federal, state or territory law or administrative arrangement. ${ }^{11}$ It is also possible that provisions of the Social Security Act 1991 (Cth), such as sections 544B(8) and 631C, may operate to exclude the possibility of an employment relationship arising, given that the PaTH internship may constitute an 'approved programme'. However, whether these provisions protect the host business and not just the federal government remains to be seen.

In the United States, New York had taken a similar approach to Australia, at least when it came to the regulation of the Work Experience Program in that state. In 1996 the United States Congress enacted the Personal Responsibility and Work Opportunity Reconciliation Act (PRWORA), which established the federally funded welfare programme Temporary Assistance for Needy Families. One of the express purposes of the PRWORA was to end the dependence of needy parents on government benefits by promoting job preparation and work. To be eligible for federal grants to fund state welfare programmes, the PRWORA required states to ensure that a specific percentage of welfare recipients participated in 'work activities', such as on-the-job training. New York enacted a welfare reform statute, the New York State Social Services Law, which complied with the PRWORA requirements and authorized the establishment of the Work Experience Program. ${ }^{12}$ As a condition of receiving welfare benefits, recipients in some cases were required to participate in this programme. Though once heralded 'the largest such program in the nation', in 2016 it was reported that the Work Experience Program was being phased out. ${ }^{13}$

The number of hours a participant of the Work Experience Program was required to engage in was calculated by the higher of the federal or state minimum wage. That is, participants were required to 'work off' their benefits. In Brukhman v Giuliani the Court of Appeals of New York held that participants of the Work Experience Program were not entitled to divide their benefit by the prevailing wage rate (as opposed to the minimum wage) on the

11 See Andrew Stewart and Rosemary Owens, Experience or Exploitation? The Nature, Prevalence and Regulation of Unpaid Work Experience, Internships and Trial Periods in Australia (Fair Work Ombudsman 2013) 75-82.

${ }_{12}$ For a summary of how the Work Experience Program commenced, see Elwell $v$ Weiss 2007 WL 2994308 (WDNY 2006).

13 Carl Campanile, 'De Blasio to Nix Workfare Program by End of the Year' New York Post (New York, 3 November 2016), https://nypost.com/2016/11/03/de-blasio-to -nix-workfare-program-by-end-of-the-year/, accessed 30 March 2021. 
basis that they were not employees for the purposes of article I section 17 of the New York State Constitution. ${ }^{14}$ The Court observed: 'Program participants simply are not "in the employ of" anyone - that is the very reason they are receiving welfare benefits and required to participate in the Program, until they can find or be placed in jobs with the customary array of traditional indicia of employment.' ${ }^{15}$

However, following Brukhman v Giuliani, a number of cases held that participants of the Work Experience Program were employees within the meaning of Title VII of the Fair Labor Standards Act. ${ }^{16}$ Indeed, in Carver $v$ State of New York, ${ }^{17}$ the New York Court of Appeals cautioned that Brukhman v Giuliani should be confined to its facts.

\subsubsection{The Use of Soft Law}

Where formal, or hard, laws do not reach - that is, laws creating legally binding obligations on individuals and organizations - soft laws formed by governmental and representative bodies can guide action. In the context of the regulation of ALMP internships, an example of this soft-law approach can be found in South Africa and, in particular, in relation to the country's largest ALMP, the Expanded Public Works Programme (EPWP). South Africa's Department of Labour has provided a 'Code of Good Practice for Employment and Conditions of Work for Expanded Public Works Programmes'18 and 'Ministerial Determination 4: Expanded Public Works Programmes' to ensure the effective implementation of the programme. The EPWP is targeted at the unemployed and particularly those from marginalized groups, including low-skilled individuals, people with disabilities, and the urban and rural poor. The interns are employed on a temporary or ongoing basis either by the government, non-government organizations or contractors. According to the Code of Good Practice for EPWPs, the interns are to be afforded the protection of the Basic Conditions of Employment Act and the Labour Relations Act. ${ }^{19}$ Arguably, this is because the interns would satisfy the broad definition of 'employee' in both Acts, given that they receive remuneration in return for their work, and assist the host organization in carrying on or conducting its business.

727 NE 2d 116 (NY, 2000).

Ibid 121.

16 See eg Stone v McGowan 308 F Supp 2d 79 (NDNY, 2004); Elwell (n 12); Carver $v$ State of New York 26 NY 3d 272 (2015).

17 Carver (n 16).

18 Hereafter referred to as the 'Code of Good Practice for EPWPs'.

19 Code of Good Practice for EPWPs, [3.2]. 
The remuneration that the interns receive must be paid at least monthly, must not be less than the EPWP wage rate, and can be paid either at a daily rate or based on the number of tasks completed. ${ }^{20}$ Normal hours of work apply, as is customary in the relevant sector, but are limited to 40 hours per week. ${ }^{21}$ The Code of Good Practice for EPWPs also provides that an intern can only be dismissed if: (1) there is a 'good reason' for the dismissal (which may relate to the intern's conduct, such as lateness); and (2) the host organization has followed a 'fair procedure', such as by investigating the incident, notifying the intern and allowing them to respond to any allegations made against them. ${ }^{22}$

\subsubsection{A Mixed Regulatory Approach}

A mixed approach to the regulation of ALMP internships can be found in Canada, and in particular in Ontario and Quebec. Ontario's social assistance programme, Ontario Works, is administered by the Ontario Ministry of Children, Community and Social Services, and includes community participation and employment placements. As the name suggests, community participation requires individuals to take part in community service activities in public or not-for-profit organizations. The placements are unpaid. Section 3(5) of the Employment Standards Act expressly excludes participants of the programme from its scope, while section 73.1 of the Ontario Works Act excludes these individuals from the scope of the Labour Relations Act. Section 73.1 sparked fierce debate in Parliament when it was introduced in 1998 as part of Bill 22, Prevention of Unionization Act (Ontario Works) 1998, as the section prevents individuals engaging in community participation activities from unionizing, bargaining collectively and striking.

A different position exists when it comes to the Ontario Works employment placements, which provide unemployed individuals with on-the-job training. The Ontario Works Directives provide that participants are afforded the protection of the Employment Standards Act and must be paid the prevailing wage rate for the position in which they are hired. ${ }^{23}$

In Quebec, Emploi Québec offers two types of financial assistance programme: a Social Assistance Program aimed at individuals who are capable

20 Code of Good Practice for EPWPs, [9.1]-[9.2]; Ministerial Determination 4: Expanded Public Works Programmes annexure, [13.1]-[13.2].

21 Code of Good Practice for EPWPs, [10.1].

22 Ibid [15].

23 Ontario Ministry of Children, Community and Social Services, 'Ontario Works Directives - 8.5: Employment Placements’ (May 2018), https:/www.mcss.gov.on.ca/ en/mcss/programs/social/directives/ow/8_5_OW_Directives.aspx, accessed 30 March 2021. 
of being employed and a Social Solidarity Program for people whose capacity to work is severely limited. To achieve the objectives of the programmes, the Minister of Employment and Social Solidarity offers employment-assistance measures, which are described in Title I of the Individual and Family Assistance Act. These employment-assistance measures can include ALMP-type internships, such as placement services and vocational training aimed at increasing workplace-related skills.

The provisions of Quebec's Act Respecting Labour Standards and Labour Code appear to apply to an employment activity engaged in within the scope of an employment measure. However, this is a general position that is subject to a number of exceptions. For instance, by virtue of regulation 6 of the Individual and Family Assistance Regulation, the provisions of these statutes do not apply to:

- work activities not governed by the Labour Code or the Act Respecting Labour Standards;

- work activities carried out under employment-assistance measures focused on training or the acquisition of skills; and

- work activities carried out under employment-assistance measures that include workplace exploration intended to explain vocational orientation or to support entry to the labour market or job preparation, for the first four weeks of each training period.

These exceptions, therefore, operate to exclude most ALMP-type internships from the scope of Quebec's labour laws.

\subsection{HEALTH AND SAFETY, WORK-RELATED INJURIES, AND DISCRIMINATION AND HARASSMENT}

As the previous section illustrated, it is not uncommon for ALMP interns to be either expressly excluded from or not specifically included in a country's labour laws. Nevertheless, even if ALMP interns do not fall within the scope of a country's employment laws, in most jurisdictions it appears that occupational health and safety, anti-discrimination and workers compensation laws apply to them. In Germany, for example, section 16d(7)VII of the SGB II states that individuals undertaking temporary extra jobs are protected by occupational health and safety laws. In Argentina, article 13(1) of Resolution MTEySS No 45/06 expressly provides that host organizations of the Programa de inserción Laboral may be given financial assistance to ensure that interns of the programme have access to the necessary safety clothes and hygiene items. 
In Canada ALMP interns are covered by provincial health and safety, anti-discrimination and workers compensation regimes. In Quebec, for example, section 11(4) of the Act Respecting Industrial Accidents and Occupational Diseases provides that, for the purposes of that legislation, persons performing work as part of a programme under Title I of the Individual and Family Assistance Act are deemed workers of the government (unless the work is performed under the responsibility of the Minister of Employment and Social Solidarity). In Ontario, the Ontario Works Directives state that host organizations of community placements must comply with the Ontario Human Rights Code, the Occupational Health and Safety Act and the Workplace Safety and Insurance Act, ${ }^{24}$ and that participants in employment placements are afforded the protection of the latter two Acts as well as the Pay Equity Act. ${ }^{25}$

In South Africa, the Minister of Labour's Code of Good Practice for EPWPs clarifies that host organizations of the EPWP must comply with the Employment Equity Act (chapters 1-2), the Occupational Health and Safety Act, and the Compensation for Occupational Injuries and Diseases Act. ${ }^{26}$ This is because interns of the EPWP are under the direction and supervision of the host organization and must receive payment for their work, thereby satisfying the definition of 'employee' in these Acts. ${ }^{27}$

In the United States, New York had adopted a similar approach to the countries discussed previously. Under section 336-c(2)(a), the New York State Social Services Law stated that a recipient of welfare assistance could be assigned to participate in a Work Experience Program only if 'appropriate federal and state standards of health, safety and other work conditions are maintained'. Further, section 336-c(2)(c) required that participants of the programme be provided with 'appropriate workers' compensation or equivalent protection for on-the-job injuries', but not necessarily at the same benefit level that regular employees receive. ${ }^{28}$ The federal government had also clarified

24 Ontario Ministry of Children, Community and Social Services, 'Ontario Works Directives - 8.6: Community Placements’ (May 2016), https:/www.mcss.gov.on.ca/ documents/en/mcss/social/directives/ow/0806.pdf, accessed 30 March 2021.

${ }_{25}$ Ontario Ministry of Children, Community and Social Services, 'Ontario Works Directives 8.5' (n 23).

26 Code of Good Practice for EPWPs, [3.2].

27 See Employment Equity Act (No 55 of 1998), s 1; Occupational Health and Safety Act (No 85 of 1993), s 1; Compensation for Occupational Injuries and Diseases Act (No 130 of 1993), s 1.

28 See also Kemp v City of Hornell 672 NYS 2d 537 (NY App Div, 1998); Covert $v$ Niagara County NY Slip Op 03870 (2019). 
that federal anti-discrimination laws applied to workfare participants. ${ }^{29}$ Indeed, the New York Court of Appeals for the Second Circuit held that participants of the Work Experience Program were 'employees' for the purposes of Title VII of the Civil Rights Code. ${ }^{30}$

In other countries ALMP interns are expressly excluded from the ambit of their social laws. This situation currently exists in Australia, at least at the federal level, as the Social Security Act 1991 (Cth) exempts a number of ALMP internships from the scope of the Work Health and Safety Act 2011 (Cth) and Safety Rehabilitation and Compensation Act 1988 (Cth). ${ }^{31}$ At the state level, all Australian jurisdictions except Victoria and Western Australia have harmonized their workplace health and safety laws. The model legislation requires host organizations to take reasonable steps to maintain the safety of 'workers', a term that is broadly defined to include a 'trainee'. ${ }^{32}$ By contrast, workers compensation statutes generally apply only to employees in the common law sense, with few drafted to extend expressly to interns. ${ }^{33}$ In relation to PaTH internships this has raised concerns that there may be a "[l]ack of adequate safety and protections for participants, including access to workers compensation arrangements'. ${ }^{34}$

Concerns about health and safety are warranted given that evidence has emerged from other countries of ALMP interns engaging in unsafe practices. An example of this can be found in China. The city of Guangzhou implements a comprehensive workfare programme, which is aimed at unemployed beneficiaries of the Minimum Living Standard Scheme aged 18-50 years (for women) and 18-60 years (for men), and which requires participants to engage in a range of social and community services in order to receive financial assistance. ${ }^{35}$ There have been circumstances where beneficiaries have been required to engage in community work that puts their physical health at serious risk. For example, one claimant 'was forced to do community work despite ill health', while another claimant, who was an acute cancer patient, was required

29 Department of Labor, 'Labor Protections and Welfare Reform' (22 May 1997), https://nclej.org/wp-content/uploads/2015/11/LaborProtectionsAndWelfareReform .pdf, accessed 30 March 2021.

30 United States $v$ City of New York 359 F 3d 83 (2004).

31 See eg Social Security Act 1991 (Cth), ss 120, 501D(4).

32 See eg Work Health and Safety Act 2011 (NSW), s 7.

33 Stewart and Owens (n 11) 105-7.

34 Senate Education and Employment Legislation Committee, Social Security Legislation Amendment (Youth Jobs Path: Prepare, Trial, Hire) Bill 2016 [Provisions] (Commonwealth of Australia 2016) 19.

35 Chak Kwan Chan and Kinglun Ngok, 'Workfare in the Undemocratic States: The Case of China' (2016) 59 Int Soc Work 479. 
'to continue doing a patrol duty in the evenings because the authority could not find someone to swap him'. ${ }^{36}$

Cases such as these illustrate the importance of ensuring that ALMP interns are afforded the protections of anti-discrimination, occupational health and safety, and workers compensation laws. They also throw into doubt the assumption that ALMP internships are of high quality, at least when compared with open-market internships, owing to the presence of the labour market intermediary. It is this assumption to which this chapter now turns.

\subsection{THE QUALITY ASPECT OF ALMP INTERNSHIPS}

In 2016, as part of its analysis of open-market and ALMP traineeships (the parlance used in Europe to refer to internships), the European Commission observed:

In the case of open market traineeships there is no third party involved further to the trainee and host organisation, which also means that the quality assurance of the traineeship becomes more difficult. ALMP-type traineeships, on the other hand, are offered to (young) unemployed or those at risk of becoming unemployed, and there is usually a public institution (most often a PES) acting as an intermediary between the host organisation and the trainee. This intermediary institution also has a supervising function in terms of traineeship quality. ${ }^{37}$

This implicit assumption that ALMP internships have better quality assurance than do open-market internships is arguably more valid for ALMP internships that are specifically governed by regulations or soft laws that set out the content of the internship and the responsibilities of the host organization and intermediary. For example, in Canada the Ontario Works Directives give the host organization of an employment placement incentives to enter into a written agreement establishing, inter alia, its responsibility to provide participants with adequate supervision and training. ${ }^{38}$ In Australia, the federal government has released $\mathrm{PaTH}$ internship guidelines that require the provider, host organization and intern to sign a PaTH internship agreement, which must record the supervisor's details and the activities the intern will complete. The host organization must also guarantee that the internship will not be used to displace existing employees or reduce an employee's hours of work. ${ }^{39}$

$36 \quad$ Ibid 485.

37 European Commission (n 2) 4.

38 Ontario Ministry of Children, Community and Social Services, 'Ontario Works Directives 8.5' (n 23).

39 Department of Employment, Skills, Small and Family Business, Guideline: Managing PaTH Internships (Commonwealth Government 2019). 
However, a distinction can be drawn between ALMP internships aimed at providing highly skilled individuals with professional work experience and those targeted at providing lower-skilled individuals with generic work experience. In relation to the latter, concerns have been raised that some of the generic or low-level work that interns must undertake lacks the required training dimension, as it is geared more towards benefiting the community than enhancing skill levels and can result in interns engaging in only the most menial of tasks. For example, the crux of Guangzhou's workfare programme in China is that beneficiaries must engage in a range of community work, including community sanitation, neighbourhood patrols, providing support to the elderly and those with disabilities, and distributing donated goods. ${ }^{40}$ While the contents of the workfare programme must be defined and recipients' attendance is monitored, they are 'not tailor-made programmes for addressing welfare recipients' employment barriers' ${ }^{41}$

Similar concerns can also be raised in relation to Ontario's community placements in Canada, which can require participants to engage in activities such as maintenance work, cleaning and kitchen help. ${ }^{42}$ As Castonguay observes, 'those work-activities in the Ontario Works program take place in a sector which is distant to the regular labour market'. ${ }^{43}$ There are also no requirements regarding the structure of the community placements. Instead, requirements on participating organizations focus on guaranteeing that: (1) the placements cannot displace any paid employment in the organization; (2) the placements cannot interfere with a participant's paid employment or an opportunity to gain paid employment (such as job searching); and (3) specific standards in relation to labour and social laws are met. ${ }^{44}$

Germany's temporary extra jobs are frequently used for community services, including work on public infrastructure. ${ }^{45}$ While the aim of these jobs is to reintegrate the unemployed into the labour market, an amendment in 2012 revoked the clause in the SGB II which required that the jobs improve recipients' professional knowledge and skills. ${ }^{46}$ What the SGB II currently requires is that temporary extra jobs meet three main conditions. First, they must be of

\footnotetext{
$40 \quad$ Chan and Ngok (n 35) 483.

$41 \quad$ Ibid 485.

42 Julie Castonguay, Benchmarking Carrots and Sticks: Developing a Model for the Evaluation of Work-Based Employment Programs (Amsterdam University Press 2009) 233.

43 Ibid.

44 Ontario Ministry of Children, Community and Social Services, 'Ontario Works Directives 8.6' (n 24).

45 Walter (n 7) 74.

46 Eleveld (n 6) 214.
} 
value to society at large, which is on par with the community services aims of Ontario's community placements and Guangzhou's workfare programme. Secondly, the temporary extra jobs must not be in direct competition with jobs that currently exist in the labour market. Thirdly, the temporary extra jobs must be additional; that is, these jobs must not currently exist in the labour market nor will they in the near future. Given this last requirement, how participants of the programme are expected to gain transferable skills is unclear, as employers are requiring other skills, that is, skills relevant to jobs that actually exist in the market. ${ }^{47}$

In the United States, New York had also taken a similar approach in relation to the regulation of its Work Experience Program. The New York State Social Services Law provided that assignments undertaken as part of the programme had to occur in the public or not-for-profit sector and serve a 'useful public purpose' ${ }^{48}$ Yet some of the assignments that participants undertook included highway maintenance duties, ${ }^{49}$ sorting paper clips and straightening nails..$^{50}$ Also of note was that section 336-c(2)(e) of the New York State Social Services Law required that the assignments undertaken could not constitute 'a substantial portion of the work ordinarily and actually performed by regular employees' nor could they result in 'the displacement of any currently employed worker'. Whether this provision was enforceable in practice was questionable. In Rosenthal $v$ City of New York, ${ }^{51}$ the Appellate Division of the New York Supreme Court held that, in order to prove a breach of section 336-c(2)(e), a plaintiff employee had to be able to identify the specific Work Experience Program participant that displaced them. However, with varying systems of municipal employment and workfare in New York City it would have been virtually impossible to establish this proof. ${ }^{52}$

\subsection{ANALYSIS AND FUTURE DIRECTIONS}

The countries discussed in this chapter have adopted a range of approaches to regulate their ALMP internships. Notwithstanding, it appears uncommon for legislation to be introduced that explicitly brings ALMP internships within the scope of labour laws by either expressly defining the internships as 'employment' or extending employment rights to particular internships.

\footnotetext{
47 Walter (n 7) 80.

48 See New York State Social Services Law, ss 336-c(1)(b), 336-c(2)(d).

49 Stone (n 16).

50 Elwell (n 12).

$51 \quad$ Rosenthal $v$ City of New York, 725 NYS 2d 20 (1st Dept, 2001).

52 Don Friedman, An Advocate's Guide to the Welfare Work Rules (Empire Justice Centre 2008).
} 
Indeed, in some countries, such as Germany and Canada, ALMP interns are expressly excluded from the scope of their employment laws. The justification for this exclusion (or lack of inclusion) in part stems from the assumption that ALMP internships are designed for the benefit of the unemployed individuals participating in these programmes by assisting their transition into the labour market. More particularly, the interns are assumed to receive a great deal more than that which they offer the host organizations and intermediaries involved; hence the arrangement in place is presumed to lack the necessary quid pro quo requirement to give rise to an employment relationship. However, as the European Commission has observed, some ALMP internships have the potential to be misused in practice to displace regular employees. ${ }^{53}$ In these instances, the interns could be regarded as engaging in productive work that directly benefits the business, which throws into doubt the assumption that there can be no employment relationship between the intern and the host organization or intermediary.

Nonetheless, even if some ALMP internships do not attract the operation of some employment laws, this should not dictate their exclusion from all forms of labour and social regulations. The values of safety and equality at work should be seen as objectives that apply to all forms of work, whether paid or unpaid, and whether or not they are undertaken as part of training. Therefore, there is no reason why regulation and, in particular, hard laws dealing with matters of work safety, workers compensation, discrimination and harassment should not apply to ALMP interns while they are at work. While this is generally true in most countries (such as South Africa) it is not completely so in others (such as Australia). Further, although some countries have chosen to use soft laws to regulate their ALMP internships, which is commendable, this approach would be more effective in assisting host organizations who want to provide interns with some level of employment and social law protection, but perhaps are unsure about what factors need to be considered, as opposed to motivating 'good' practices in organizations where 'bad' practices are entrenched. For example, the impact this type of approach would have on host organizations that deliberately use ALMP interns as a source of cheap labour to displace regular workers is questionable. ${ }^{54}$

At the very least, some modified hard-law entitlements should be established that afford ALMP interns some level of protection. However, in cases

53 Kari P Hadjivassiliou, Emanuela Carta, Tom Higgins, Catherine Rickard, Suzanne Ter-Minassian, Flavia Pesce and others, Study on a Comprehensive Overview on Traineeship Arrangements in Member States: Final Synthesis Report (European Union 2012) 88.

${ }^{54}$ Similar concerns have been expressed in relation to quality frameworks. See ibid 847-8. 
where minimum wages or other employment benefits are modified, it is important that governments bear in mind a significant point of principle articulated by the International Labour Office's (ILO's) Committee of Experts on the Application of Conventions and Recommendations:

Recalling the overarching principle of equal pay for work of equal value, the Committee considers that persons covered by apprenticeship or traineeship contracts should only be paid at a differentiated rate where they receive actual training during working hours at the workplace. In general, the quantity and quality of the work performed should be the decisive factors in determining the wage paid. ${ }^{55}$

The committee went on to urge governments to regulate and monitor 'apprenticeship, internship and other work-experience schemes, including through certification, to ensure they allow for a real learning experience and do not replace regular workers' ${ }^{56}$ However, as already noted, some ALMP internships, and particularly those aimed at lower-skilled individuals, are geared more towards benefiting the community than enhancing skill levels or ensuring 'a real learning experience', to use the parlance of the committee. That is, the focus is less on supporting the interns' reintegration into regular employment and more on ensuring that they give back to society, which has provided its generosity (welfare payments). ${ }^{57}$

In other instances, the regulations in place prohibit ALMP interns from participating in work ordinarily undertaken by regular employees. The mischief to which this proscription is directed is the use of cheaper or free ALMP interns to displace regular fully paid workers. While regulation that guards against this risk is important, it can at times come with the consequence that ALMP interns engage only in the most routine, low-skilled and menial of tasks. This work can still instil a level of structure and discipline in the interns' work lives, by requiring them 'to get out of bed, shave, dress up and arrive on time', ${ }^{58}$ but it ignores the fact that some welfare recipients already possess extensive previous work experience and it does not provide them with the skills and training necessary to facilitate their entry into the modern workforce. The involvement of the intermediary is not of itself sufficient to assure that ALMP internships will deliver on the promise of useful training and skill development.

55 Committee of Experts on the Application of Conventions and Recommendations, Minimum Wage Systems: General Survey of the Reports on the Minimum Wage Fixing Convention, 1970 (No 131), and the Minimum Wage Fixing Recommendation, 1970 (No 135) (International Labour Office 2014) [188].

56 Ibid.

57 Noah D Zatz, 'What Welfare Requires from Work' (2006) 54 UCLA L Rev 373; Amir Paz-Fuchs and Anja Eleveld, 'Workfare Revisited' (2016) 45 Indust LJ 29.

58 Paz-Fuchs and Eleveld (n 57) 33. 
Increasing labour and social inclusion and introducing regulation to ensure there is sufficient quality assurance might deter the use of ALMP internships. That is, the increased bureaucracy and cost could dissuade some organizations from offering these internships. From one perspective, this would not be an unfortunate consequence because it would assist in closing the door on ALMP internships that are used to exploit interns, displace regular workers and undermine a nation's labour and social regulations. Nor would it be the only potential consequence. ALMP internships should be realigned with the laudable aims of labour and social inclusion and quality assurance to preserve their central purpose of ensuring that the interns, armed with the required skills, capabilities and experience, transition effectively into a modern workforce. 